\section{Relationships between genotypes and phenotypes in natural populations of the European flounder (Platichthys flesus) under different types of contamination in estuaries}

\section{J. Marchand, ${ }^{1}$ L. Quiniou, ${ }^{2}$ \\ J. Laroche ${ }^{2}$}

'UPRES EA 2160 Mer, Molécules, Santé, Université du Mans, Le Mans; '2LEMAR, UMR 6539 CNRS/UBO/IRD/Ifremer, Institut Universitaire Européen de la Mer, Plouzané, France

\section{Introduction}

The integration of population genetics in ecotoxicology may be pertinent i) to detect possible differential physiological capacities or performances between individuals carrying particular alleles or genotypes, and ii) to explain their potential resistant or sensitive characters, sometimes resulting in increasing or decreasing frequencies in contaminated systems. ${ }^{1}$

Different studies were conducted on the genetic and physiological responses of the European flounder (Platichthys flesus) to pollution stress, especially in estuaries along the Atlantic coast of France.,3 The authors highlighted that: i) particular alleles and genotypes (allozyme data) may be likely influenced (indirectly or directly) by chemical stress; ii) fish carrying these alleles or genotypes displayed higher DNA integrity over the whole contaminated populations. In addition, relationships between genotypes and phenotypes highlighted specific trends related to pollutant estuarine characteristics.

In a more recent study, ${ }^{4}$ new DNA markers were explored in P. flesus; cDNA and genomic sequences of the genes encoding the glyceraldehyde-3-phosphate-deshydrogenase (GAPDH), the cytosolic creatine kinase(CK), the prostaglandin D synthase (PGDS) and the betaine homocysteine methyl-transferase (BHMT) were characterized. ${ }^{4}$ The tumor suppressor $p 53$ gene was also considered in this study, the gene structure being already described. The exploration of the genetic polymorphism was carried out on several flounder populations along the French coast. The frequency of the p53-A allele was shown to be higher in contaminated populations (collected in the Gironde, Loire, Seine and Vilaine estuaries) compared to a reference site (Ster estuary), this increase ranging from $12.4 \%$ to
$13.7 \%{ }^{4}$ In the Vilaine estuary, mean increases of $10 \%$ in BHMT-A and PGDS-A allele frequencies were also observed compared to the Ster estuary. ${ }^{4}$ Globally, the analysis of genetic diversity within populations and genetic differentiation suggested that the patterns of genetic structuration detected for flounders were probably more linked to local selection acting on the candidate genes than to the consequence of possible isolations by distance, or different histories of colonization. ${ }^{4}$

In the present report, new investigations were conducted on flounder populations stemming from environmentally contrasted estuaries. Our main objective was to confirm the possible selective effects of the contaminant on the candidate genes (GAPDH, CK, PGDS, $B H M T$, p53) by exploring the couplings between genotypes and phenotypes in the field.
Correspondence: Justine Marchand, Laboratoire Mer, Molécule, Santé UFR Sciences et techniques, Université du Maine, Avenue Olivier Messiaen, 72085 Le Mans, France.

Tel. +39.02.43.83.32.50.

E-mail: justine.marchand@univ-lemans.fr

Key words: European flounder, population genetics, selection, pollution, BHMT, p53.

Conference presentation: part of this paper was presented at the ECOBIM meeting, 2013 May, Montréal, Quebec, Canada.

This work is licensed under a Creative Commons Attribution NonCommercial 3.0 License (CC BYNC 3.0).

(C) Copyright J. Marchand et al., 2013

Licensee PAGEPress, Italy

Journal of Xenobiotics 2013; $3($ s1):e14

doi:10.4081/xeno.2013.s1.e14

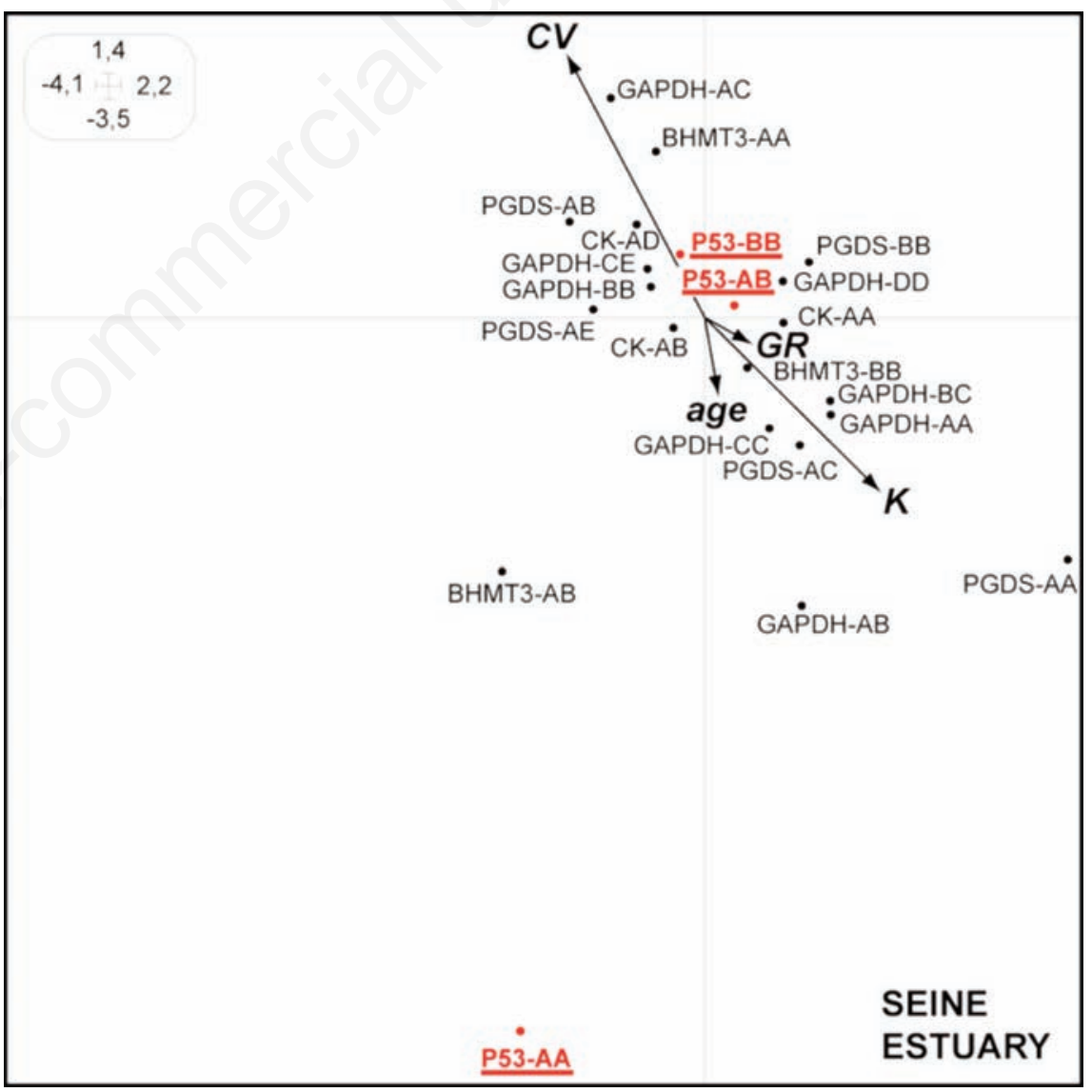

Figure 1. Synthetic Hill and Smith analysis for European flounders from the Seine estuary linking quantitative variables (CV, coefficient of variation of DNA content of blood cells; GR, growth rate; $K$, condition factor; $F$, relative fecundity) and qualitative data (genotypes) The main 2 first axes explain $54 \%$ of the total variance (ovoid box shows the limit of the plan). 


\section{Materials and Methods}

Fish were sampled from four polluted estuaries and one moderately contaminated system: ${ }^{3,5,6}$ i) the Seine undergoes a diffuse contamination similar to ones reported in heavily polluted estuaries of North America; the chemical stress of the Loire is rather similar, though organic pollutant concentrations are three times lower; ii) the Vilaine catchment is mainly impacted by agriculture and, thus high levels of pesticides are encountered as well as high winter polycyclic aromatic hydrocarbons (PAHs) levels; iii) the Gironde is also displaying a diffuse contamination, but mainly characterized by high heavy metals levels (zinc, cadmium, copper); iv) the Ster basin receives reduced inputs of domestic and agricultural effluents, and no industrial waste; it is thus considered as the reference site in our study.

Forty flounders from each estuary were caught in winter (January and February 2003), just before spawning activity's optimum. The average age was estimated using otoliths (mean $\pm 95 \%$ confidence interval): $2.05 \pm 0.9$ years, $2.43 \pm 0.71$ years, $2.42 \pm 0.47$ years, $1.23 \pm 0.45$ years, $2.72 \pm 0.79$ years for respectively the Seine, Loire, Gironde, Vilaine, and Ster populations.

Total length and somatic weight were measured for each fish. For each female, ovaries were weighted and a sample was set in a Gilson solution ${ }^{7}$ for the estimation of the relative fecundity: F (absolute fecundity/somatic weight). ${ }^{3}$ The individual growth rate (GR) between the annuals marks of the first and second winter was estimated using otoliths. The condition factor (K) linked to energy reserves was calculated using the relation: $\mathrm{K}=$ somatic weight / (total fish length). ${ }^{3}$

Changes in DNA content reflecting chromosomal damages were estimated from blood samples by flow cytometry. We assumed that high coefficients of variation of blood cell DNA content (CV) are linked to high variation in the DNA content in blood cells of a single individual, i.e. to high chromosomal damages induced by chemicals. ${ }^{3}$

DNA extractions were performed on muscle samples collected. cDNA and gene characterizations, as well as the PCR-SSCP (Single Strand Conformation Polymorphism) technique used to detect genetic polymorphism were previously explained. ${ }^{4}$

A Hill and Smith synthetic analysis ${ }^{8}$ was carried out on mature female data using the ADE4 software, ${ }^{9}$ computing both genetic and physiological variables, in order to explore possible relationships between qualitative data $(e . g$. genotypes) and quantitative data (e.g. phenotypes).

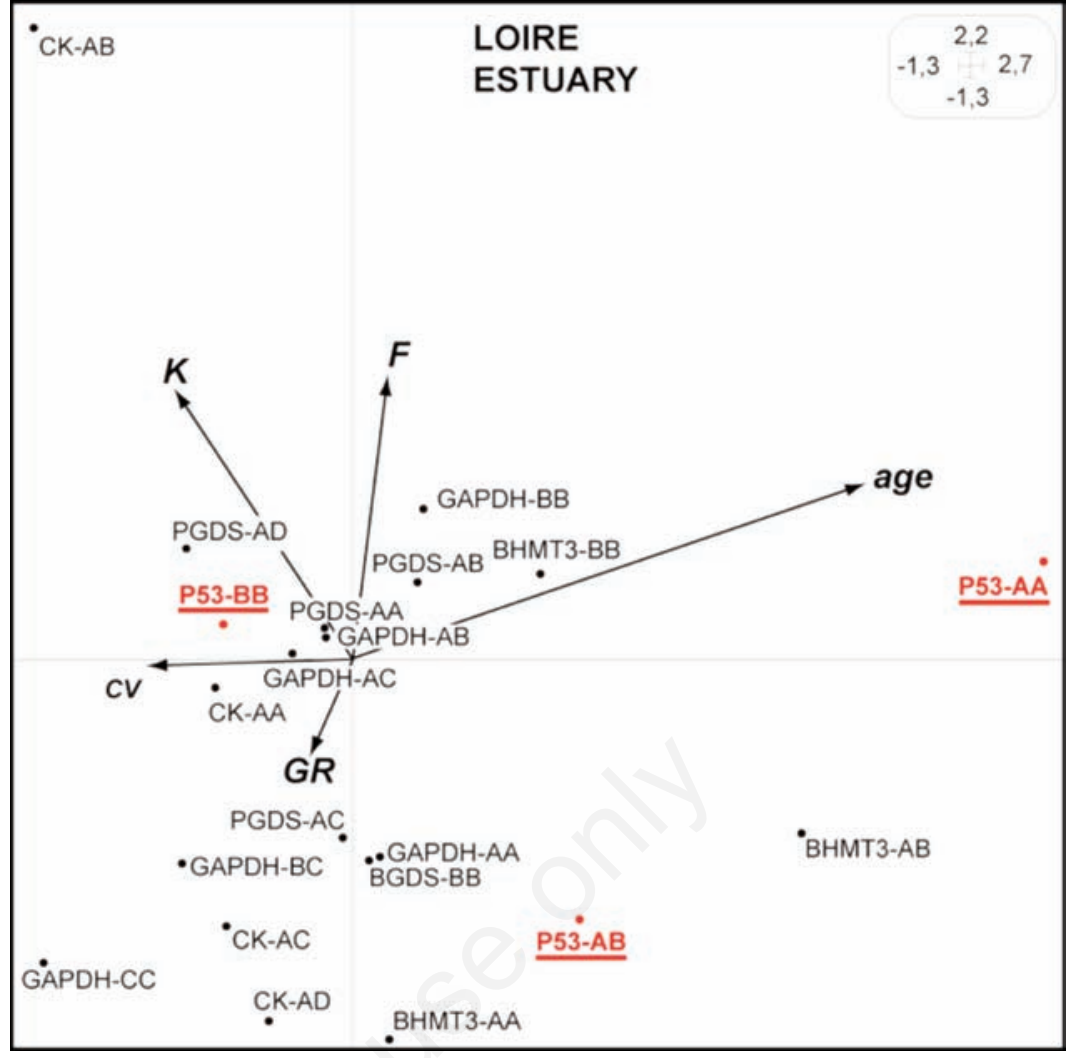

Figure 2. Synthetic Hill and Smith analysis for European flounders from the Loire estuary. The main 2 first axes explain $48 \%$ of the total variance. See Figure 1 caption for details.).

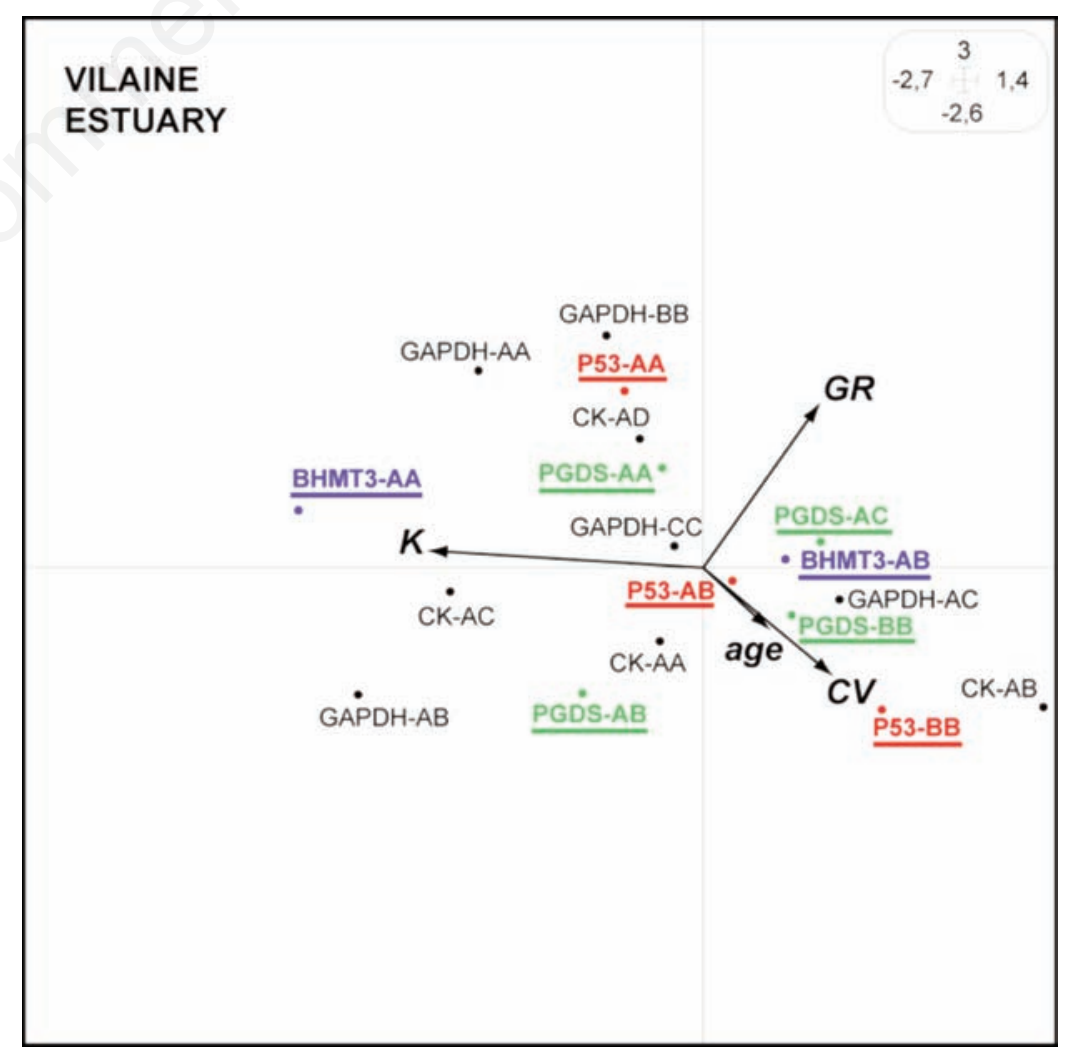

Figure 3. Synthetic Hill and Smith analysis for European flounders from the Vilaine estuary. The main 2 first axes explain $52 \%$ of the total variance. See Figure 1 caption for details. 


\section{Results and Discussion}

Synthetic Hill and Smith analyses carried out on the Seine and Loire data show a similar negative correlation between CV (coefficient of variation of DNA content in blood cell) and fish age (Figures 1 and 2). Furthermore, the genotype p53-AA is clearly associated to low CVs (high DNA integrity) comparatively to those detected for the genotypes $\mathrm{p} 53-\mathrm{AB}$ and p53-BB (Figures 1 and 2). These results suggest that in these estuaries (displaying a complex mixture of heavy-metals and organic pollutants), individuals carrying the p53-AA genotype could display a better ability to maintain their DNA integrity and probably a better survival compared to individuals carrying other p53 genotypes. . $^{10,11}$ The same trend has already been shown (considering allozyme data) in previous studies on $P$. flesus $s^{2,3}$ and on freshwater fish populations. ${ }^{12,13}$

In the Vilaine estuary (mainly polluted by pesticides and PAHs), a better DNA integrity is again observed for the genotypes p53-AA compared to genotypes $\mathrm{p} 53-\mathrm{AB}$ and $\mathrm{p} 53-\mathrm{BB}$, whereas a positive correlation is observed between $\mathrm{CV}$ and fish age (Figure 3). Furthermore, lower DNA damages are observed for the genotypes BHMT3-AA and PGDS-AA compared to the other BHMT and PGDS genotypes (Figure 3).

The synthetic Hill and Smith analysis conducted in the Gironde system (mainly polluted by heavy metals), do not show any relationship between the p53 genotypes and the level of DNA damages (Figure 4), p53-AA being linked to high fish age and growth rate comparatively to genotypes $\mathrm{p} 53-\mathrm{AB}$ and $\mathrm{p} 53-\mathrm{BB}$.

The genotypes-phenotypes couplings performed in the reference system (the Ster estuary, Figure 5) show a contrasted situation compared to what is found in polluted systems (Seine, Loire, Vilaine), the genotypes p53-AA, PGDS-AA being associated to high CVs (low DNA integrity).

Globally, our previous report ${ }^{4}$ allowed to detect an increase of particular alleles in polluted systems (p53-A in Seine, Loire, Vilaine; BHMT3-A \& PGDS-A in Vilaine) compared to a reference estuary (Ster). In the present study, individual physiological performances (phenotypes) were integrated in order to establish genotype-phenotype relations. A better ability to maintain DNA integrity was found in flounders carrying the A allele at the p53, BHMT3 and PGDS loci, in the previous polluted systems. We suggest that the polymorphism of p53, BHMT3 and PGDS in the European flounder could be related to the possible tolerance of populations facing complex mixtures (mainly organic pollutants) and in particular to their potential role at the cellular level: regulation of cell cycle - apoptosis; ${ }^{4}$ detoxification - epigenetics - antioxidative responses., ${ }^{41,15}$

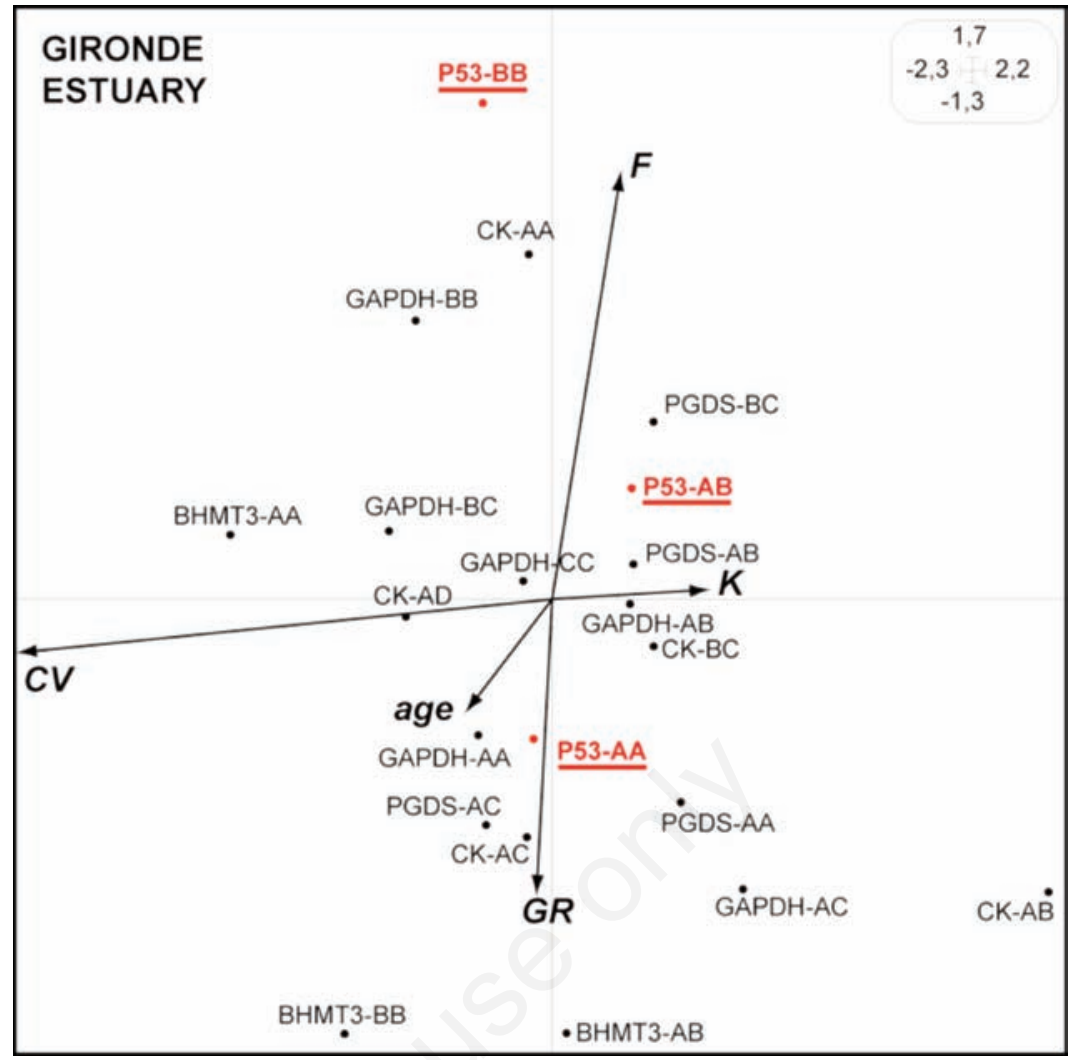

Figure 4. Synthetic Hill and Smith analysis for European flounders from the Gironde estuary. The main 2 first axes explain $52 \%$ of the total variance. See Figure 1 caption for details.

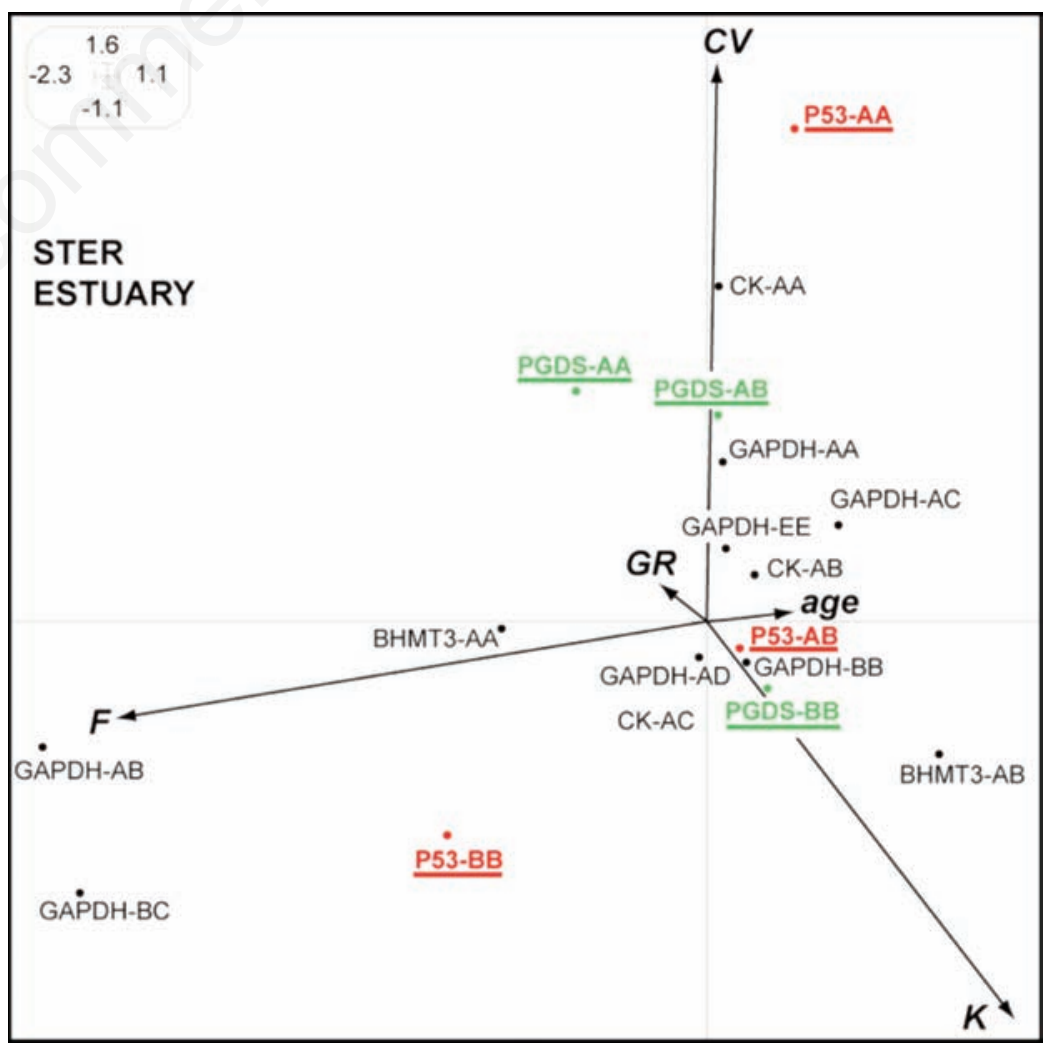

Figure 5. Synthetic Hill and Smith analysis for European flounders from the Ster estuary. The main 2 first axes explain $44 \%$ of the total variance. See Figure 1 caption for details. 
Furthermore, the general concept of a resistant genotype in a contaminated environment being counter-selected in a pristine system ${ }^{16}$ is confirmed in the present study: a particular high DNA damage is associated to individuals carrying the genotypes p53-AA and PGDS AA in the reference estuary.

Finally in the present report, we observe that the analysis of persistent fish populations living in chronically contaminated estuaries, compared to populations living in pristine estuaries, can provide new insights into the identification of candidate genes involved in the tolerance of fish to chemical stress in the field. This hypothesis is confirmed by a recent study performed in the United States, highlighting the functional role of the AHR2 polymorphism in the resistance of Fundulus heteroclitus to high levels of contaminants in industrial sites. ${ }^{17}$

\section{References}

1. Marchand J, Denis F, Laroche J. Evolutionary toxicology \& transcriptomic approaches. In: Amiard-Triquet C, Amiard JC, Rainbow PS, eds. Ecological biomarkers: indicators of ecotoxicological effects. Boca Raton, FL: CRC Press; 2013. pp 361383.

2. Marchand J, Tanguy A, Laroche J, Quiniou L, Moraga D. Responses of European flounder Platichthys flesus populations to contamination in different estuaries along the Atlantic coast of France. Mar Ecol Prog Ser 2003;260:273-84.

3. Marchand J, Quiniou L, Riso R, Thébault
MT, Laroche J. Physiological cost of tolerance to toxicants in the European flounder Platichthys flexus along the French Atlantic coast. Aquat Tox 2004;70:327-43.

4. Marchand J, Evrard E, Guinand B, Cachot J, Quiniou L, Laroche J. Genetic polymorphism and its potential relation to environmental stress in five populations of the European flounder Platichthys flesus, along the French Atlantic Coast. Mar Environ Res 2010;70:201-9.

5. Laroche J, Gauthier 0, Quiniou L, Devaux A, Bony S, Evrard E, et al. Variation patterns in individual fish responses to chemical stress among estuaries, seasons and genders: the case of the European flounder (Platichthys flesus) in the Bay of Biscay. Environ Sci Pollut Res 2013;20:738-48.

6. Evrard E, Devaux A, Bony S, Burgeot T, Riso R, Budzinski H, et al. Responses of the European flounder Platichthys flesus to the chemical stress in estuaries: load of contaminants, gene expression, cellular impact and growth rate. Biomarkers 2010;15:111-27.

7. Simpson AC. The fecundity of the plaice. Fish Invest. ser II 1951;17:1-27.

8. Hill MO, Smith AJE. Principal component analysis of taxonomic data with multistate discrete characters. Taxonomy 1976;25:249-55.

9. Thioulouse J, Chessel D, Dolédec S, Olivier JM. ADE-4: a multivariate analysis and graphical display software. Stat Comput 1997;7:75-83.

10. Avise J. The evolutionary biology of aging, sexual reproduction, and DNA repair. Evolution 1993;47:1293-301.

11. Barja G. Mitochondrial free radical produc- tion and aging in mammals and birds. Ann N Y Acad Sci 1998;854:224-38.

12. Mc Farland V, Inouye L, Lutz C, Jarvis A, Clarke J, Mc Cant D. Biomarkers of oxidative stress and genotoxicity in livers of field-collected brown bullhead, Ameiurus nebulosus. Arch Environ Contam Toxicol 1999;37:236-41.

13. Larno V, Laroche J, Launey S, Flammarion P, Devaux A. Responses of chub (Leuciscus cephalus) populations to chemical stress, assessed by genetic markers, DNA damage and cytochrome P450 1A induction. Ecotoxicology 2001;10:145-58.

14. Marchand J, Tanguy A, Charrier G, Quiniou L, Plee-Gauthier E, Laroche J. Molecular identification and expression of differentially regulated genes of the european flounder, Platichthys flesus, submitted to pesticide exposure. Mar Biotech 2006;8:275-94.

15. Evrard E, Marchand J, Theron M, Pichavant-Rafini K, Durand G, Quiniou L, et al. Impacts of mixtures of herbicides on molecular and physiological responses of the European flounder Platichthys flesus. Comp Biochem Physiol 2010;152:321-31.

16. Changnon NL, Guttman SI. Differential survivorship of allozyme genotypes in mosquitofish populations exposed to copper or cadmium. Environ Toxicol Chem 1989;8:319-26.

17. Wirgin I, Roy NK, Loftus M, Chambers RC, Franks DG, Hahn ME. Mechanistic basis of resistance to PCBs in Atlantic tomcod from the Hudson river. Science 2011;331:1322 5 . 